\title{
AVALIAÇÃO DA PREVALÊNCIA E MORTALIDADE DE MENINGITES VIRAIS NO ESTADO DO PARANÁ NO PERÍODO DE JANEIRO DE 2015 A JANEIRO DE 2020
}

\author{
EVALUATION OF THE PREVALENCE AND MORTALITY OF VIRAL \\ MENINGITES IN THE STATE OF PARANÁ IN THE PERIOD FROM JANUARY \\ 2015 TO JANUARY 2020
}

Gabriel Henrique Azeredo*, Mariana Domingos Gonçales, Giovana Parra Pelisari, Gustavo Bacelar Peraro.

UNINGÁ - Centro Universitário Ingá, Maringá, PR, Brasil. *bielhaz@gmail.com

\section{RESUMO}

A Meningite Viral é um quadro de alterações neurológicas que decorrem da inflamação das camadas de tecido que recobrem o Sistema Nervoso Central e medula (as meninges), e dos espaços preenchidos por Líquido Cérebro-espinhal (Líquor), que estão entre elas. De fato, é um quadro que usualmente evolui de forma benigna, no qual a principal conduta terapêutica se restringe ao tratamento dos sintomas do acometido, podendo-se considerar corticosteroides apenas em casos na qual a inflamação se mantém constante, intensa e conjunta de sinais como a hipertensão intracraniana. De forma geral, nota-se maior prevalência de quadros onde os Vírus do grupo Enterovírus são os agentes etiológicos, e com maior prevalência em indivíduos menores de 5 anos (apesar de poder acometer indivíduos de outras faixas etárias). Em caráter da alta prevalência e de um bom prognóstico, o estudo em questão buscou analisar comparativamente o número de internações e a taxa de mortalidade em casos de Meningites Virais no estado do Paraná. Para tanto, foi feita uma coleta de dados por meio do DATASUS, de forma que foram consideradas as variáveis: faixa etária (0 a 60 anos), sexo, internamento, óbito e taxa de mortalidade, dos casos que ocorreram entre janeiro de 2015 e janeiro de 2020. No período citado, foram registradas 1.085 internações por Meningite Viral no Paraná, sendo 626 de pacientes do sexo masculino e 459 do sexo feminino. Desses casos, 21 resultaram em óbito (uma taxa de mortalidade equivalente a 1,94\%), com maior prevalência entre o sexo masculino que totalizou 12 mortes. Como era esperado de acordo com a literatura, as internações foram maiores na faixa de 0 a 5 anos, totalizando 454 casos (260 masculinos e 194 femininos), de forma que 2 evoluíram para óbito $(0,44 \%$ de mortalidade) sendo um de cada sexo. Na faixa dos pacientes de 5 a 19 anos houveram 319 internações (183 masculinas e 136 femininas), sendo que dessas, 2 pacientes do sexo feminino evoluíram a óbito $(0,63 \%$ de mortalidade). Entre os pacientes de 20 a 39 anos, os dados mostraram que 196 pacientes foram internados (116 homens e 80 mulheres), com um aumento do número de óbitos que subiu para 6 , sendo todos pacientes do sexo masculino (3,06\% de mortalidade). Já na faixa entre 40 e 59 anos, houveram 116 internações (67 masculinas e 49 femininas), com aumento para 11 óbitos $(9,48 \%$ de mortalidade), sendo 6 do sexo feminino. Devido aos dados apresentados, 
infere-se que não há distinção quanto ao sexo tanto pelo número de internações como pelo número de óbitos registrados, contudo, nota-se que há um aumento proporcional direto entre a idade dos pacientes e o número de óbitos registrados e uma proporcionalidade indireta entre essa idade e o número de internações. Com efeito, constatou-se que quanto maior a idade, menor o número de casos, porém maior é o risco óbito, e quanto menor for a idade, maior o número de casos, porém com menor risco de evolução para o óbito.

Palavras-chave: Fatores etários. Internação. Meningite. Mortalidade. Óbitos. Paraná. Viral. 